Warm up

\title{
Pursuing the dream
}

\section{P McCrory}

t has long been known that sporting performance can be significantly enhanced by boosting the blood's oxygen carrying capacity through the use of blood doping practices. This method was banned after the 1984 LA Olympics where there was considerable speculation that the silver medal winning US men's pursuit cycling team used such a method to improve their performance. Previous to this, there were numerous stories of elite athletes purportedly drinking reindeer blood or the like, to achieve their extraordinary performances.

Of course transfusing blood into your veins carries significant risks such as immune reactions as well as viral infections. Not surprisingly when synthetic erythropoietin (EPO) became available in the 1980s the smarter athletes used this method in preference to blood doping. At the 2000 Sydney Olympics, the first sanctioned test to detect EPO became available. As a result, the rather old fashioned blood doping method has been making a comeback.

Just one problem however, it would appear that non-autologous transfusions can now be detected. An antigen test is now being marketed that can detect foreign cells in an athlete's blood. The ABO blood group system has a number of easily detected major antigens that are used in cross matching blood. The new doping test uses 15 minor antigens to detect whether foreign blood is present in the sample.

The only theoretical potential problems are in athletes who have had a bone marrow or stem cell transplant, have non-identical twins (where placental cross transfer may occur), or in situations where there is chimeric embryo fusion in utero.
This test has now been used in practice. In the recent Tour de Spain, US cyclist Tyler Hamilton was caught using this test. Hamilton has denied the charges of doping. ${ }^{1}$ Both his A and B sample were positive according to this professional team-Phonak. Phonak have also announced that they will examine the validity of the test using "independent scientists." Hamilton won a gold medal at the Athens Olympics and looks certain to keep his medal due to the fact that although his A sample from Athens was similarly positive using this test, the B sample had been stored incorrectly and could not be retested.

Where next for the technologically inclined athlete? Well, autologous doping is still undetectable and perhaps artificial haemaglobins may be next. As usual the athletes will push the envelope to remain ahead of the drug testers. One would have to wonder why we don't make it legal and allow more complete medical supervision of such practices. Is it the athlete's health that is paramount or some outdated Victorian ideal of amateurism?

Br J Sports Med 2004;38:665

\section{REFERENCE}

1 Aschwanden C. No cheating in the blood test. New Scientist 20042 October 2004:17. 


\section{Expression of concern about content of which Dr Paul McCrory is a single author}

This paper is authored by Dr Paul McCrory. During 2021 and 2022 there was an investigation by BJSM and BMJ which found that some of his work was the product of publication misconduct. Such misconduct includes plagiarism, duplicate publication, misquotation and misrepresentation in publications in respect of which he was listed as the sole author. ${ }^{1}$ We are placing a notice to readers on all content in relation to which he is identified as the sole author to alert them to the conclusions of our investigation.

(C) Author(s) (or their employer(s)) 2022. No commercial re-use. See rights and permissions. Published by BMJ.

Br J Sports Med 2022;0:1. doi:10.1136/bjsports-2022-106408eoc

D) Check for updates

\section{REFERENCE}

1 Macdonald H, Ragavooloo S, Abbasi K. Update into the investigation of former BJSM editor-in-chief Paul McCrory. Br I Sports Med 2022. 